\title{
Academic integrity in an emerging democracy: How university students in a former Soviet Republic balance achievement and success in education
}

\author{
Michael Houdyshellm ${ }^{1}$ \\ Florida Gulf Coast University, Fort Myers, FL, USA
}

\begin{abstract}
After the fall of the Soviet Union, former Soviet Republics found themselves needing to revise and sometimes create systems affecting their emerging democracies. In education for example, the former Soviet system of teaching and learning was now open for new and different methods of instruction and evaluation. In countries like the Republic of Moldova, the revision and creation of an educational system was made even more problematic as a multi-lingual and multiethnic population saw opportunities in more open and accessible pathways through education and into business. These opportunities gave rise to the pressures of success, and at times, by any means necessary. This has created an environment where academic dishonesty has become prevalent at all levels of education especially in higher education. This paper examines the attitudes, beliefs and practices of university students surrounding academic integrity in the Republic of Moldova.

Keywords: Academic integrity, cheating, plagiarism, emerging democracies, academic dishonesty, Republic of Moldova
\end{abstract}

\section{Introduction}

As former Soviet Union republics gained independence in the early 1990s they struggled with creating and maintaining institutions necessary for successful democracies. However, independence also presented new opportunities for individual freedoms, and citizen participation in a wide array of social participatory arenas such as government, business and education. Economic modernization (began before the Soviet communism collapse) created a middle-class who were increasingly familiar with cultural and education. They increased their activity in business and free-enterprise (Chirot, 1990), and all citizens began to expand their presence in national and local government. In particular, the existing middle-class and those that followed came of age attending Soviet system schools. When communism collapsed and newly independent countries assumed control of social institutions like public education, states and individuals began to search for different models. Countries borrowed from various educational models based on history, politics and future needs. Many of the former Soviet republics are still grappling with transforming and using different educational models today.

\section{Country case study}

One example is the Republic of Moldova, which had been under the Russian empire, part of Romania or in the Soviet Union for almost its entire modern history (Chinn \& Roper, 1995). It has struggled to create state systems such as education that appeals to its multi-ethnic and multi- lingual population. Because of its past and current ties to Romania and the Soviet Union, Moldova borrows from both countries in creating an educational system that caters to its multi-lingual population. Unfortunately for Moldova, a confusing past identity spread over a current multi-ethnic society where individuals see increased opportunities gained through wealth and education have all combined to create an ethical and moral vacuum in education. In former Soviet Union republics like Moldova an environment exists where democratic freedoms expand access to information, yet the pressure to succeed in a developing democracy creates an educational system where exercising academic integrity is increasingly challenged. Stated in simplest terms: Moldovan students see cheating, plagiarism and other forms of academic dishonesty as an easier and more direct route to educational and professional success. This paper examines attitudes and perceptions of nine Moldovan university students interviewed about their experiences in the Moldovan educational system. Based on the responses of the students, it attempts to shed light on where the attitudes of academic dishonesty developed, why it continues and perhaps what the future may look like for the Moldovan educational system.

\footnotetext{
${ }^{1}$ E-mail; mhoudyshell@fgcu.edu
} 


\section{Literature Review}

Academic integrity and issues of academic dishonesty continue to plague higher education (Danielsen, Simon, \& Pavlick, 2006; Fontana, 2009; Lipka, 2009; McCabe, 2009; McCabe et al., 2006; Rosamond, 2002; Wilkerson, 2009). In fact, university students tend to view academic dishonesty with very little concern for the potential consequences of their actions, sometimes seen as a 'victimless crime' (Gomez, 2001). A variety of factors contribute to why students commit academic dishonesty. Some research points to the rise in income disparities around the world as contributing to how society and students view the importance of earning a degree and a good income (Lau, 2010; Maak, 2007; Mayhew, et al., 2010). Other research points to increased unethical behavior by highly visible political and educational figures (Lafer, 2014; Boehm, Justice, \& Weeks, 2009; McCabe, 2009). Regardless of the influence, students begin to use these kinds of justifications for engaging in academic dishonest behavior (Blankenship \& Whitley, 2000; Gomez, 2001; Nath \& Lovaglia, 2009; Petress, 2003; Smith \& Davis, 2003).

As societal issues begin to influence student's perceptions and actions surrounding academic dishonesty, researchers began to look for individual or personal factors contributing to a student's propensity to engage in academic dishonesty. In Crown and Spiller's 25 year look at academic dishonesty (1975-1995), they found while gender difference declined over time, males and females viewed and engaged in academic dishonesty differently (1998). However, Whitley found female students demonstrated more negative attitudes surrounding cheating compared to their male counterparts even though reported frequencies of academic dishonesty for females and males were relatively similar (2001).

Different than gender, the increased presence of technology in education over the past 10 years has only increased incidences of academic dishonesty. As different technological tools and access have increased so has their use in education. Computers, cell phones, and the Internet have created increased instances of academic dishonesty and misuse in education (Boehm, et al., 2009; Choi, 2009; Danielsen, et al., 2006; Maitland, 2007).Increased use of technology in education has lowered the barriers to academic dishonesty (Etter, Kramer \& Finn, 2006), and essentially made it much less difficult to conduct then in the past (Boehm, et al., 2009; Choi, 2009; Danielsen, et al., 2006; Maitland, 2007; Witherspoon, Maldonado, \& Lacey, 2012). This study examines these societal factors and others influencing attitudes and behaviors related to academic dishonesty from the perspective of Moldovan university students.

\section{Methodology}

\section{Moldovan Educational System}

The Moldovan educational system is structured in a similar manner as in the United States. There are some differences worth mentioning for the purposes of this article. Schools for younger students, grades first through fourth are considered primary schools structured very similar to schools in the United States. Students can also attend a type of school called a gymnasium typically the middle part of their education which focuses on strong academic learning and secondary education, ending at the ninth or tenth grade. Secondary education is either in a general school which ends at grade eleven and typically does not permit students to enter higher education, or in what is called a lyceum, which finishes with a baccalaureate exam and entrance into higher education. In grades ten through twelve there are also vocational and training schools, and other discipline specific colleges, which do not require the baccalaureate exam but do allow students to continue with higher education (Foreign Credits, 2013). While working with a youth nongovernmental organization (NGO) for ten months in a small Moldovan village I had an opportunity to experience the primary, middle and secondary parts of the educational system. However, because of my prior experience working in the United States higher education system this study focuses on students studying at a state university in the capital city of Chisinau, Moldova.

\section{Description of Participant Sample}

During the fall 2012 term, I was invited to teach three English topic courses at two different state universities in the Republic of Moldova. This was my first experience working with college age Moldovan students in the classroom. In my own classroom observations and in discussions with Moldovan college students and non-Moldovan teachers (Fulbright professors and United States Peace Corps English Education volunteers), particular patterns of behavior began to emerge relating to academic dishonesty. Teachers reported frequent occurrences of students using 'cheat sheets' and plagiarizing information from the internet; students would openly discuss past instances of cheating and writing research papers based on the work of someone else without any citation. In response to this apparent lack of concern for academic 
honesty, I sought out students for a qualitative study to discuss this phenomenon in the Moldovan education system. I solicited participation from third year students studying to become English language teachers in a course I was team-teaching with a Moldovan partner teacher on English grammar methodology. I also visited one master's level class with students studying in an English Studies program in the Foreign Language and Literature department. In each situation, students were given my contact information and told to voluntarily make contact with me if they were interested in discussing academic dishonesty (I used the term 'dishonesty' interchangeably with 'integrity' as this was a more familiar term for these students who all spoke English as a second language). Ultimately, I had a sample size of nine (eight Moldovan students and one Ukrainian student living in Moldova) semi-structured individual interviews in English asking participants twenty-five questions relating to demographic background, academic dishonesty and their experience in the Moldovan educational system (See Appendix). At the end of each interview, participants were given copies of the interview questions, their answers as written. At the conclusion of each interview, each participant signed a statement indicating the truthfulness of their responses and their willingness to participate. No other human subjects' permissions were given as this study was not part of any official course or sponsored research at an institution of higher education (IHE). Four of the participants were graduate students, and the other five were all third year, upper-level undergraduate students. The participants ranged from 21 to 24 years of age; seven were female and two were male. I met with each participant either on campus in a center dedicated to American studies or at a local coffee shop. The interviews took place over an approximate two week time frame, between January and February 2013. I used only the first name of each interview participant to help safeguard their identity as each student was still enrolled in university. Each interview lasted approximately one to one and half hours long; at the conclusion of each interview each participant reviewed their responses and gave signed consent to use their interview for this research. One participant requested a follow-up interview as she felt her responses and English language ability were not strong during the first interview due to illness. At the end of each interview I gave each participant the opportunity to review the final publication and all agreed. After each individual interview, I transcribed each session where I identified and coded themes and common responses in order to support or refute my original hypothesis.

\section{Findings}

\section{Employment and Dishonesty}

Because of Moldova's past history as part of the former Soviet Union, the original premise behind this research related to the Soviet Union's influence on past and current Moldovan educational beliefs and practices. Believing that the Soviet ideals were the driving force behind students' attitudes towards academic dishonesty, I explored this idea with participants. What I discovered was quite the opposite, in fact many participants related their knowledge of the past educational system or in conversations with their parents that during the Soviet period in Moldova, academic dishonesty was not as frequent and the consequences for committing it were more severe. This is in direct contradiction to what occurs now in the educational system where cheating is more prevalent, appearing to start at younger ages and in part the attitude to succeed propels the desire to engage in academic dishonesty. In contrast to this I began to explore the idea that emerging democracies create new freedoms which often bring the choice of how much responsibility one takes for exercising these freedoms. Participants I interviewed told of a desire to achieve high marks (grades) and diplomas at any cost. Not only did this include academic dishonesty but many participants also talked of bribing professors and administrators. Dishonesty in business including tax evasion and bribery is often cited by Moldovans as rampant and difficult to change. In exploring the link between academic and business dishonesty, participants made clear connections with the two often reporting that the pressure of securing a good job caused students to be dishonest academically. Paradoxically, I also explored whether business leaders were more concerned about hiring graduates who they believed were academically dishonest. Most participants believed they cared but since most workers are hired on a probationary status any individual who had cheated would be found to be deficient during this period because they did not know the required knowledge. Most participants also believed dishonesty in business was more serious than in academics. Participants believed that academic dishonesty only negatively impacted the individual versus in business where the potential to harm multiple people had more serious implications. "... worse in business because consequences are worse" (Alisa, 22). "If you cheat as a doctor you can't help your patient" (Egor, 21). However, some participants seemed resigned to the fact, at least for Moldovans, that dishonesty was part of the culture of doing business. "Business is business-right to be dishonest..." (Ludmila, 24). "You should do well in business and everything will work" (Egor, 21). 


\section{Satisfaction in One's Own Work}

During all the interviews I never specifically asked any participants if they had been dishonest during their academic career. During the course of each interview all participants volunteered whether or not they had engaged in academic dishonesty. Only three participants made it a point to tell me they had never cheated in school. Of the remaining participants, all related times of cheating or plagiarism but it usually was when they were younger and they were no longer engaging in this behavior. Of the three students who made it a point to say they had never cheated, two talked of the satisfaction in doing their own work and getting their own marks (grades) even if they may differ from their peers. "I get lower marks but they are my own" (Elena, 23). Another tied her desire not to cheat to doing her own work. "I don't cheat I want my diploma to be mine" (Inna, 21). Finally, the third participant simply stated "I never cheated" (Egor, 21). For students who discussed past instances of cheating, many connected it to their lack of interest, necessity or need for a particular subject. "I have to cheat, for example in Math, my brain is not ok this way" (Alisa, 22). "...it depends on the subject, for example astronauts need to learn physics or astronomy but a painter learning chemistry?" (Sergiu, 22). One participant cited the amount of preparatory work Moldovan students have to complete compared to their American counterparts (this student spent one year studying at an American university). While studying in America she mentioned never having to cheat. "...things were prepared in a way you did not need to (cheat)" (Victoria, 22). In comparison, she thought it was "not as wrong" for Moldovan students to cheat because sometimes "...there were too many subjects, couldn't prepare, no time, more preparation than in the U.S. Amount is too big" (Victoria, 22). The sentiment of too much material or unnecessary material was repeated by many of the participants.

\section{Passive and Active Academic Dishonesty}

The literature on academic dishonesty makes a distinction between two types of academic dishonesty: passive and active. Passive dishonesty relates to actions like using another individual's answers on an exam, sharing exam questions or observing someone cheating and not reporting it (Anistal, et al, 2009). Using another individual's research and passing it off as your own (plagiarism) or using a cell phone to transmit questions and answers are all considered types of active academic dishonesty. To perform a self-check with participants about the difference between passive and active forms of academic dishonesty, I asked each participant to define plagiarism in their own words. I then gave them a dictionary definition of plagiarism. Every participant was able to clearly define and discuss the idea of plagiarism. I then asked them to discuss which type of academic dishonesty, passive or active they thought was more damaging. Most participants believed active dishonesty was more dangerous and damaging to education. "Bigger consequences" (Sergiu, 22) said one participant. Participants recognized how using someone else's work as your own was much more serious, almost criminal. “...stealing someone else's ideas” (Victoria, 22). "You have stolen someone else's thoughts" (Egor, 21). "...it's not your own thoughts, ideas, like stealing” (Elena, 23). A few participants believed passive dishonesty was more troublesome in education but for different reasons. One participant thought if someone was using or copying your exam you could be targeted for cheating even though you might be 'innocent' (Alisa, 22). However, two other participants thought passive was worse than active dishonesty because while you might be using someone else's work, you could also be learning something from it. In contrast, passive dishonesty was “...just copying” (Aliza, $24 \&$ Liuda, 21). I returned to specific elements of passive and active dishonesty; reporting someone who witnesses cheating and the use of technology later in the article.

\section{Academic Dishonesty and the Soviet Influence}

Even as my original premise about the historical Soviet effects on the Moldovan education system changed, I still wanted to explore any possible lingering influences. I asked participants if they believed it was more acceptable to engage in academic dishonesty in Moldova because of its former status as a Soviet republic. Again, most participants believed during the Soviet era cheating was less frequent, less tolerated and punished more severely. Several cited the respect for the profession of teaching during the Soviet times as one reason there was less academic dishonesty. "Teacher was well respected. Now teachers (are) not paid well, people avoid (teaching) with good skills" (Victoria, 22). "(I) had five teachers from the Soviet times (they) would not let anyone cheat. People become teachers in post-Soviet (times) so maybe they don't care, not paid well. Don't care about doing it properly so why bother?" (Irina, 21). "Sometimes they (teachers) don't care". "Teachers cheated when they were students" (Elena, 23). Some participants put the blame on the lack of punishment or fear of punishment for increased levels of academic dishonesty. 
"Because no one punishes or makes (you) ashamed (Alisa, 22). One participant blamed the lack of motivation and Moldovan students are not hard working (Aliza, 23). Another said Moldovan students "we are lazy" (Liuda, 21). One participant talked of students traveling to Moldova to study during the Soviet era but now they go abroad. "The educational system is not as good" (Egor, 21). Another participant believed students protect each other (when they cheat), they would not tell the professor, "...no whistle blowing" (Ludmila, 24). Returning to the theme of more choice and responsibility with emerging democracies, a participant believed the educational system was tougher during Soviet times, "...now with more liberties, more choices..." students have fewer restrictions and more opportunities to cheat (Sergiu, 22). In general, it seemed not only was academic dishonesty reportedly less frequent in the Moldovan educational system during the Soviet era, teaching was a more respected profession. This led me to explore with participants the role of teachers and academic dishonesty in Moldova.

\section{The Influence of Teachers on Academic Dishonesty}

When participants were asked about the prevalence of academic dishonesty in Moldova versus the United States, many believed it was higher in former Soviet republics like Moldova. Some students placed responsibility of cheating on teachers, believing teachers had cheated as students and because of school pressure to succeed were often providing students with information in preparation for examines or administrative classroom visits. One participant believed because only stronger students were asked questions, other students had to cheat to compensate for the lack of instruction. "Teachers only ask strong students to participate" (Victoria, 22). Or in other cases, one participant related her experience with teachers just giving students the information for an exam, "(the) teacher told them what is on test" (Elena, 23). When asked why this would occur a participant talked about 'open classes' with teachers giving answers to all students and the pressure to have a 'successful' class when teachers from other schools would visit (Liuda, 21). Another participant talked about the Dean visiting her school and having the teachers 'preparing' the students the previous day because they want to look good during the visit (Alisa, 22). Interestingly, this student also believed older students felt they had an 'obligation' to help others (younger students) to cheat if they knew the information (Alisa, 22). This belief seemed to arise from an idea of "legacy" in handing down information from older to younger students, and how younger students would witness the teacher 'preparing' students for an administrative visit and seeing older students engage in cheating (Alisa, 22). I wanted to explore any cultural links (such as obligation or legacy) about academic dishonesty within the Moldovan educational system and asked participants to discuss this idea.

\section{Influence of Culture on Academic Dishonesty}

As students discussed the idea of academic dishonesty linked to Moldovan cultural beliefs familiar themes re-emerged including feelings of obligation, existing legacy of cheating, disinterest in subject matter, earning money, securing a good job, and blame for teachers who allow cheating to occur or create an environment where cheating is implicitly tolerated. One participant talked of how teachers don't want to "look bad" or damage "their reputation" so help students prepare for exams with answers (Alisa, 22). Another participant said teachers do not discuss cheating much with students and the problems arise from almost the first days of school (Ludmila, 24). "Schools say don't do it but still let it get by" (Sergiu, 22). However, other participants linked the idea of succeeding professionally and earning a good salary as a stronger cultural link with academic dishonesty. One participant related how she would earn 10 lei (Moldovan currency) for a 10 mark (highest grade) from her grandfather (Aliza, 24). Other participants believed wealth is what matters in Moldova, and the desire to succeed regardless of the method often influenced academic dishonesty. "Money matters-people show it so you cheat to get a good job, to make lots of money" (Inna, 21). Finally one participant was unsure about a link between Moldovan culture and academic dishonesty as she believed (like many emerging democracies) that Moldovan cultural values were changing rapidly and continuing to evolve (Victoria, 22). After discussing cultural links with academic dishonesty in Moldova I then wanted to explore how one's own moral or ethical beliefs might influence or be influenced by academic dishonesty.

As participants discussed how certain elements in the Moldovan educational system or culture might influence academic dishonesty, I also wanted to explore how one's own personal moral or ethical beliefs could influence views on academic dishonesty. I asked participants how academic dishonesty and personal moral and ethical beliefs were related. Responses were somewhat varied on this topic ranging from the belief that cheating was ok depending on the situation to viewing academic dishonesty as a direct reflection on one's character and person. The degree of severity for cheating mattered to some participants 
who believed it was not harmful to cheat. One participant believed cheating on tests was "not a big deal" (Sergiu, 22) yet again returned to the theme of academic dishonesty versus your professional life. "(If it's) related to work (it's) more important, impacts future more" (22). Another participant connected it to not just academics but all of life, "(it's) connected to society, sometimes we have to cheat to save our lives" (Aliza, 24). One participant discussed supporting cheating in the past in relation to helping others succeed but no longer engaged in this behavior because she believed it was time "...(to) prove to yourself what you are worth" (Inna, 21). Finally, a participant discussed how she was still quite tolerant of cheating believing it was "ok to cheat" relating back to the lack of preparation by teachers in not covering the materials adequately or if there was a lack of resources available for students (Victoria, 22). Even as some participants believed some forms of academic dishonesty were at best necessary in life and at worst the fault of others, other participants viewed academic dishonesty as a direct reflection of one's character.

\section{Ethics, Morals and Academic Dishonesty}

As I discussed a connection with academic dishonesty and one's own moral and ethical beliefs, several participants believed cheating reflected who you were as a person. "Used to getting something for not doing much" was how one participant viewed it. She believed if someone got used to cheating "he gets used to easier way" (Alisa, 22). Another participant equated cheating with general dishonesty in how it "influences us, creating a picture of us in front of others" (Egor, 21). One participant was very affected by cheating and said it was not ok or tolerable in any situation (Ludmila, 24). Ethical behavior was only mentioned specifically once in which a participant believed if someone was ethical "...it should be in all spheres, it's not fair, (a person) is a hypocrite if they cheat" (Elena, 23). While a tolerant view of cheating remained in some participants, others had formed significant aversion and negative reaction to academic dishonesty in the moral and ethical fabric of their lives and in the lives of others.

\section{The Prevalence of Academic Dishonesty in Moldova}

Since this was a study about attitudes and reactions relating to academic dishonesty with Moldovan students and participants reacted differently to instances of cheating, I wanted to explore how widespread of a problem participants thought academic dishonesty was in Moldova. I asked all participants if they agreed or disagreed with the following statement: Academic dishonesty is not a widespread problem in the Moldovan education system. No participant agreed with this statement and many returned to familiar themes discussed earlier such as seeing it as part of the culture, identifying teachers as part of the problem and the connection between getting good marks (grades) and earning a diploma. Many participants believed the problem and the frequency of cheating only increased as students aged and entered university. One participant believed it was widespread in academics and especially at the undergraduate level (Ludmila, 24). Some participants cited the lack of punishment for students engaged in cheating, "it's accepted and very rarely punished" (Victoria, 22). All of the participants studied in the capital city of Moldova but some had grown up in rural areas of Moldova. One participant believed cheating was more prevalent in rural areas (Sergiu, 22). The issue of using bribes to obtain good marks (grades) or diplomas was also cited as a symptom of academic dishonesty. "Bribing is a big problem, specialists get diploma, they know nothing, and they cheat. Bribing for marks or diploma is worse than cheating" (Alisa, 22). One participant believed bribing in school was more prevalent in rural areas (Sergiu, 22). Academic dishonesty and bribes were part of the culture in Moldova, "impossible to change, part of culture, mentality" (Egor, 21). A few participants offered suggestions to change the environment of academic dishonesty, a theme I will return to later in the article. Essentially most participants believed changing the mentality about academic dishonesty started with younger students and involved teachers. I explored the idea of younger versus older students and asked participants if they believed there were any differences between genders involving academic dishonesty.

\section{The Progression of Academic Dishonesty}

During the interviews I explored how the possible changes in the frequency of cheating changed as students aged through the Moldovan educational system. Participants were split between believing academic dishonesty occurred more frequently with younger students or instead increased as students were older. In the case of younger students, some participants thought there was increased frequency because it was more allowed by teachers, "our teachers are part of the problem, more passive" (Sergiu, 22). "Everything starts with the teacher" (Ludmila, 24). However, the same participant also believed parents were part of the problem when younger students cheat. "Parents (do) not care about cheating (they) just 
care about good marks and diploma" (24). One participant thought younger students cheated more frequently because “...they don't care about their future. When you are older you start to think about what you need and your future." (Egor, 21). Relating her own experience one participant also believed the environment influenced her experience with cheating. " ...we were programmed to do this, we saw other students, and teachers encouraged us for exams" (Alisa, 22). For participants who believed cheating was more prevalent with older students some simply believed older students knew how to cheat better versus younger students (Aliza, 24). Or you simply find more ways to cheat (Luida, 21). However, one participant who believed older students cheated more frequently than younger students, felt the need to cheat eventually became less frequent for some, especially as they progressed through university (Victoria, 22). Because all of the participants in this study grew up with an increasing use of technology, I would return to the idea of finding more or in some cases better ways to cheat later in the article. After exploring the frequency of academic dishonesty between younger and older students I also wanted to discuss how gender could influence feelings about cheating. Even though my study included three times as many female participants as males, I wanted to explore any possible differences relating to gender and views of academic dishonesty.

\section{Gender and Academic Dishonesty}

In most wealthy industrial countries around the world the trend of women enrolling and earning college degrees continues. In the United States for example, in the years $2007-2008$ women were $57 \%$ of the undergraduate enrollment and earned $57 \%$ of all degrees conferred (U.S. Department of Commerce report, 2011). In graduate education this trend continues as 11 percent of all individuals aged 25-34 with two or more years of graduate school are women compared to 8 percent of men (2011). In nations of the developed world this trend continues as six out of ten undergraduate degrees conferred are on women (OECD, 2012). In Moldova there are no official statistics available on the differences in attendance between females and males but in the Language Department of Moldova State University where these students are enrolled most of the students are women. In a recent course taught for future English Language teachers out of sixty registered participants only five were male. Because of this educational gender gap I wanted to explore with participants if there was any influence on perceptions about academic dishonesty.

I asked participants if they believed one specific gender was more predisposed to engaging in academic dishonesty especially in higher education. Some participants commented on the noticeable difference in females versus males enrolled in their specific language department and believed it was hard to comment on any differences. However, other participants did make distinctions between the two genders and academic dishonesty. A few participants believed women cheated less because they studied more (Victoria, 22) or believed women wanted better marks (grades) and (males) learn what we need (Sergiu, 22). Another participant believed women cheated more in high school but in university it was more equal (Ludmila, 24). When asked why, one participant said women are more experienced at cheating than men, for example they write more on a cheat sheet (Inna, 21). Women are more "accurate" and "...like to write and know everything" (Egor, 21) was the response from another participant. One participant believed teachers were again part of the issue as they were more tolerant towards males who cheat (Victoria, 22). With such a small participant group it was not entirely clear if given the numbers were more equal between men and women in a study about academic dishonesty if the answers would be similar. After exploring differences in gender related to academic dishonesty I wanted to return to how age influenced decisions to engage in academic dishonesty.

\section{Age and Academic Dishonesty}

Most participants believed as students aged they did not necessarily cheat more, in fact a few participants said older students, especially those in university, would cheat less because they could be more interested in the subject matter. Some participants believed the advent of technology and its widespread use in Moldova such as faster internet connections and more advanced mobile phones contributed to academic dishonesty. "Methods have changed, you become more creative" as you get older (Victoria, 22). Students who are younger use a handwritten cheat sheet but when they get older it gets more restrictive but you can use more technology (Sergiu, 22). Several participants echoed the increased use of technology for use in cheating such as "... something in your ear connected to your phone (Elena, 23). "Techniques have changed with technology-cellphone, headphones, tablets" (Ludmila, 24). There was some disagreement between participants who thought younger students cheated more or less than older students. Those who believed younger students cheated more frequently cited issues of more restrictions for academic dishonesty and the 
idea that as students entered university their need to cheat sometimes decreased. (Sergiu, 22 \& Ludmila, 24).

Participants who believed older students cheat more frequently gave different reasons. One participant believed as you got older you could become "...more serious about subject (and) you cheat less" (Alisa, 22). A few participants believed as you age you get better at cheating, becoming what one called "more expert cheaters" (Inna, 21). The importance of good grades and diplomas become more important as you get older cited one participant, "it is more important, their future depends on marks or diploma" (Elena, 23). Finally, one participant stated simply she believed older students cheated because "people are lazy, they don't want to learn" (Inna, 21). Older or younger, all participants believed students cheated at some point in their academic careers and technology was only making it easier and more accessible.

\section{The Future of Academic Dishonesty in Moldova}

Since most of the participants admitted to some form of academic dishonesty during their academic careers, and many of the participants represented the future of Moldovan education as teachers or interpreters, a few volunteered how they thought the frequency of academic dishonesty might be decreased. One participant believed the consequences for cheating should be more severe such as expulsion or even charging students for missing classes or cheating (Egor, 21). Returning to a theme from earlier in the article, one participant thought education and subject matter should be more interesting which in turn would create less instances of academic dishonesty (Alisa, 24). A final participant's thought concerning how to combat academic dishonesty in the future was more thorough in her assessment of how to correct the problem. "Look at causes of system, ...change curriculum, (more) training for teachers (and) introduce (issues of cheating) on the syllabus" (Victoria, 22). These ideas were the most advanced in their attempt to correct academic dishonesty in the Moldovan educational system.

\section{Discussion Of Findings}

After years of Soviet influence, Moldova is emerging as a multi-lingual, multi-cultural country in transition. Embracing democratic ideals while balancing a lingering Soviet mentality has created a difficult time for Moldovan's educational system. Democratic freedoms have created new opportunities for Moldovan youth to expand their wealth and achievement yet created an environment where gaining academic success is often valued more than ethical and truthful behavior. Results from this small study reveal a deep seated problem with how students, young and old, male and female, view and participate in forms of academic dishonesty.

\section{Gender}

Research since 2010 has shown that incidents of academic dishonesty are less prevalent in female students compared with their male counterparts (Honny, Gadbury-Amyot, Overman, Wilkins, \& Petersen, 2010; Kobayashi \& Fukushima,2012; Salleh, Hamid, Alias, Ismail, \&Yusoff, 2011;Saulsbury, Brown, Heyliger, \& Beale 2011). Clariana, Badia and Cladellas studied 306 secondary school and university students in Spain. Their research found males (boys) end up cheating significantly more than females (girls) (2013). Responses from the nine Moldovan university students interviewed seem to support the idea that males cheat more than females as a few participants believed females cheated less than their male counterparts. However, not everyone believed this idea, in fact, one participant thought females cheated more than males once in university. And still one participant believed the reason males cheated more than females was because teachers tolerated cheating among male students more than females. The small sample size of this study does not lend itself to making significant correlations between gender and academic integrity in relation to prior research.

\section{Ethics and Morals}

Factors contributing to the decision to commit academic dishonesty tend to correlate more positively with internal as opposed to external motivating factors such as internal motivation and honesty (David, 2014; Ozfidan, \& Burlbaw, 2016). While some study participants still had a favorable view of academic dishonesty in their own lives, several participants described a negative almost visceral reaction to the practice of academic dishonesty, linking honesty to all parts of one's life. There was some mention of how acting dishonestly in an academic setting or other parts of life could influence how others view us as individuals. Not surprisingly based on similar research (Thorkildsen, Golant, \& Richensin, 2006; 
Teodorescu \& Andrei, 2008), most participants believed their friends and fellow classmates engaged in academic dishonesty more than themselves.

Believing their friends engaged in academic dishonesty more than themselves, participants still believed they wouldn't report their friends if they observed or knew of academic dishonesty. Chapman and Lupton found similar responses in their study of students from Hong Kong and the United States, with both groups believing their friends engaged in academic dishonesty more than themselves (2004).

\section{Employment}

The desire to obtain a well-paying and secure position after graduation was not lost on any of the nine study participants. Based on data from the World Bank's Poverty and Equity database, $12.7 \%$ of the Moldovan population were living below the national poverty line in a country with just over 3.5 million people (2017). In 2013, the unemployment rate in Moldova was nearly eight percent (2017), and graduating with a college degree was seen as a way to increase employment opportunities for young adults. This also increased the propensity for students to commit incidents of academic dishonesty or cheating, the sooner the degree is completed more opportunities to find employment increase.

Obtaining high marks (grades) and subsequently a diploma or degree was worth the risk of being discovered according to the participants, and created a higher temptation to not only engage in academic dishonesty but also in some cases to bribe professors to receive better scores. Lupton, Chapman \& Weiss also found students have such pressures to obtain good employment that it drives students to engage in academic dishonesty (2000). Similar results were reported in a study on undergraduate students and their attitudes towards academic dishonesty (Meng, Othman, D'Silva, \& Omar, 2014). Again, study participants cited a strong connection between engaging in academic dishonest behaviors and securing employment after completing their degrees. The only distinction was made when entering a career field such as medicine, with high impact on the well-being of other people. This is supported by research done by Burke, Polimeni \& Slavin (2007), who reported higher incidents of academic dishonesty in more rigorous fields of study such as accounting, engineering and medicine. Academic dishonesty leading to a career in these situations had more serious implications for participants. This is troublesome because as economies and employment have a downturn, the incidents of academic dishonesty increase as pressures to obtain employment increase.

\section{Aging In}

While some research suggests that age does play a role in the prevalence of academic dishonesty (Salleh, et. al., 2011), the participants were split on whether this mattered or not. Some cited a belief in reducing the reliance on cheating as one got older and entered employment. Yet interestingly, many participants thought the problem of cheating increased as one became an older student, while others argued that it was more prevalent at younger ages because there was less of concern about the future. Academic dishonesty can occur at any age or grade, and did not appear to have as strong of a correlation as other factors.

\section{Technology Usage}

As technology has become a normal component in a student's education, this includes using it to cheat. Ross asserts increased use of technology has also, to a certain extent, contributed to the increased rates of student academic dishonesty (2005). With the advent of more sophisticated technology, ease of access to information on the internet and an increased usage rate of new programs, online or digital academic dishonesty has increased in higher education (Kauffman and Young, 2015). None of this was lost on study participants, many believed changes in technology influenced its usage in cheating.

\section{The Roles of Others and Culture}

As participants delved into reasons why academic dishonesty occurred, blame was passed to teachers and parents alike. Passive teachers or parents only focused on good marks, were other factors cited by participants for academic dishonesty. McCabe et al. (2006) suggests teachers could be part of the problem and solution to curb academic dishonesty. Flynn (2003) makes suggestions for teachers to minimize cheating including being more proactive in spending more time to ensure students don't cheat.

The culture of succeeding and doing well (monetarily) found traction among study participants. As earlier, many felt the pressures to earn money and expressed how wealth influenced the decision to commit academic dishonesty. As an emerging democracy, Moldova feels the effects from the ideals of success 
influencing all aspects of life, positive and negative. As an established democracy with world renowned universities, American students have lower frequencies of academic dishonesty compared to their European counterparts (Mangus, et al., 2002) and (Lupton et al., 2000). Flynn found evidence that culture setting was found to be a "significant predicator of academic dishonesty" (2003).

\section{Conclusion}

From teachers to technology, this study showed how and why students engage in academic dishonesty. As beliefs about certain ethical and moral beliefs related to forms of cheating become blurred, the desire to earn good marks, get a diploma and obtain a job begin to weave throughout the cultural fabric and normalize academic dishonesty in education. As democracy imparts freedoms, the responsibility of those freedoms begins to weigh heavily on the ability to make choices impacting ones progress. Moldovan students are currently experiencing this weight and how this impacts their educational success and future. Continued study of academic dishonesty in the Moldovan educational system would help provide further insight into the causes, consequences and potential solutions of this difficult phenomenon.

\section{References}

Anistel, I, Anistel, M. \& Elmore, R. (2009). Academic dishonesty and intention to cheat: a model on active versus passive academic dishonesty as perceived by business students. Academy of Educational Leadership Journal. 13(2), 17-25.

Blankenship, K. L., \& Whitley, B. E. (2000). Relation of general deviance to academic deviance. Ethics \& Behavior, 10(1), 1-13.

Boehm, P., Justice, M., \& Weeks, S. (2009). Promoting academic integrity in higher education. The Community College Enterprise, 15(1), 45-61.

Burke, J. A., Polimeni, R. S., \& Slavin, N. S. (2007). Academic dishonesty: A crisis on campus. The CPA Journal, 77, 58-65.

Chapman, K. J. \& Lupton, R. A. (2004). Academic dishonesty in a global educational market: a comparison of Hong Kong and Americanuniversity business students. International Journal of Educational Management, 18(7), 425 - 435.

Chinn, J. \& Roper, S. D. (1995). Ethnic mobilization and reactive nationalism: The case of Moldova. Nationalities Papers, 23(2), 291-325.

Chirot, D. (1990). What happened in Eastern Europe in 1989? Praxis International, 10(3+4), 278-305.

Choi, C. (2009). The pull of integrity. ASEE Prism, 18(7), 29-33.

Ciscel, M. (2008). Uneasy Compromise: Language and education in Moldova. International Journal of Bilingual Education and Bilingualism. 11(3-4), 373-395.

Clariana, M, Badia, M, \& Cladellas, R. (2013). Academic cheating and gender differences in Barcelona (Spain). Summa Psicologica UST. 10(1), 65-72.

Crown, D. E., \& Spiller, M. S. (1998). Learning from the literature on collegiate cheating: A review of empirical research. Journal of Business Ethics, 17,683-700.

Danielsen, R. D., Simon, A. F., \& Pavlick, R. (2006). The culture of cheating: From the classroom to the exam room. Journal of Physician Assistant Education, 17(1), 23-29.

Education at glance 2012: OECD Indicators. Chapter C-Access to education, participation and progression. Retrieved fromhttp://www.oecd.org/edu/eag2012.htm.

Etter, S., Cramer, J.J. \& Finn, S. (2006). Origins of academic dishonesty: Ethical orientations personality factors associated with attitudes about cheating with information technology. Journal of Research on Technology in Education, 39(2), 133-155.

Flynn, R. T. (2003). Confronting academic dishonesty in the accounting classroom: A cultural experience.Accounting Education, 12,437-439.

Fontana, J. (2009). Nursing faculty experiences of students' academic dishonesty. Journal of Nursing Education, 48(4), 181-5.

Gomez, D. (2001). Putting the shame back in student cheating. Education Digest, 67(4), 1-6.

Honny, J. M., Gadbury-Amyot, C. C., Overman, P. R., Wilkins, K.,\& Petersen, F. (2010). Academic integrity violations: A nationalstudy of dental hygiene students. Journal of Dental Education, 74(3), 251-260.

Kauffman, Y., \& Young, M. F. (2015). Digital plagiarism: An experimental study of the effect of instructional goals and copy-and-paste affordance. Computer and Education, 83, 44-56. 
Kobayashi, E., \& Fukushima, M. (2012). Gender, social bond, and academic cheating in Japan. Sociological Inquiry, 82(2), 282-304.

Lafer, S. (2014). Democratic Design for the Humanization of Education. Journal of Ethnic and Cultural Studies, 1(1), 6-12.

Lau, C. L. (2010). A step forward: Ethics education matters! Journal of Business Ethics, 92, 565-584.

Lipka, S. (2009, April). Colleges sharpen tactics for resolving academic-integrity cases. The Chronicle of Higher Education, 55(31), A20.

Lupton, R. A., Chapman, K. J., \& Weiss, J. E. (2000). A cross-national exploration of business students' attitudes, perceptions, andtendencies toward academic dishonesty. Journal of Education for Business, 75, 231-235.

Maak, T. (2007). Responsible leadership, stakeholder engagement, and the emergence of social capital. Journal of Business Ethics, 74(4), 329-343.

Magnus, J. R., Polterovish, V. M., Danilov, D. L., \& Savvateev, A. V. (2002). Tolerance of cheating: An analysis across countries. Journal of Economic Education, 33, 125-135.

Maitland, R. (2007, September). Disturbing trends in education. Oral Health, 97(9), 53-54, 57.

Mayhew, M., Seifert, T., \& Pascarella, E. (2010). A multi-institutional assessment of moral reasoning development among first-year students. Review of Higher Education: Journal of the Association for the Study of Higher Education, 33(3), 357-390.

McCabe, D. (2009). Academic dishonesty in nursing schools: An empirical investigation. Journal of Nursing Education, 48(11), 614-23.

McCabe, D. L., Butterfield. K. D., \& Trevino, L. K. (2006). Academic dishonesty in graduate business programs: Prevalence, causes, and proposed action. Academy of Management Learning and Education, 5, 294-305.

Meng, C. L., Othman, J., D’Silva, J. L., \& Omar, Z. (2014). Influence of neutralisation attitude in academic dishonesty among undergraduates. International Education Studies, 7, 66-73.

Nath, L., \& Lovaglia, M. (2009). Cheating on multiple-choice exams: Monitoring, assessment,and an optional assignment. College Teaching, 57(1), 3-8.

Ozfidan, B., \& Burlbaw, L. M. (2016). Perceptions of bilingual education model in Spain: How to Implement a bilingual education model in Turkey. Journal of Ethnic and Cultural Studies, 3(1), 49-58.

Petress, K. C. (2003). Academic dishonesty: A plague on our profession. Education, 123(3), 624-628.

Prina, F (2012, October). Language policies or language politics? The case of Moldova. This paper presented at the Conference on "Minority representation and minority language rights: Origins, experiences and lessons to be learned." Cluj-Napoca.

Rosamond, B. (2002). Plagiarism, academic norms, and the governance of the profession. Politics, 22(3), 167-174.

Ross, K. A. (2005). Academic dishonesty and the Internet. Communications of the ACM, 48, $29-31$.

Salleh, M. I. M., Hamid, H. A., Alias, N. R., Ismail, M. N., \& Yusoff,Z. (2011). The influence of gender and age on the undergraduate's academic dishonesty behaviors. In Sociality and Economics Development (pp. 593-597). Kuala Lumpur, Malaysia: Book series 10, International Proceedings of Economics Development Research.

Saulsbury, M. D., Brown, U. J., Heyliger, S. O., \& Beale, R. L. (2011).Effect of dispositional traits on Pharmacy students' attitude towards cheating. Journal of Pharmaceutical Education, 75(4), 1-8.

Smith, L., \& Davis, J. (2003). An examination of student cheating in the two-year college. Community College Review, 31(1), 17-34.

Teodorescu, D., Andrei, T. (2009). Faculty and peer influences on academic integrity: college cheating in Romania. Higher Education, 57, 267-252.

Thorkildsen, T. A., Golant, C. J., \& Richensin, L. D. (2006). Reaping what we saw: cheating as a mechanism of moral engagement. InAnderman, E., Murdock, T. (Eds). Psychology of academic cheating. Washington: Academic Press. 171-202.

The World Bank (2017). Poverty \& Equity. Retrieved from http://povertydata.worldbank.org/poverty/country/MDA

Trading Economics (2017). Moldova unemployment rate. Retrieved from http://www.tradingeconomics.com/moldova/unemployment-rate 
Whitley, B. E., Bichlmeier Nelson, A., \& Jones, C. J. (1999). Gender differences in cheating attitudes and classroom cheating behavior: A meta-analysis. Sex Roles, 41, 657-680.

Witherspoon, M., Maldonado, N., \& Lacey, C. (2012). Undergraduates and academic dishonesty. International Journal of Business and Social Science. 3(1), 76-86.

Wilkerson, J. (2009). Staff and student perceptions of plagiarism and cheating. International Journal of Teaching and Learning in Higher Education, 20(2), 98-105.

U.S. Department of Commerce and Executive Office (2011).Women in America: Indicators of social and economic well-being. Retrieved fromhttp://www.whitehouse.gov/sites/default/files/rss_viewer/Women_in_America.pdf

ForeignCredits (2013). Education system in Moldova. Retrieved from http://www.classbase.com/Countries/Moldova/Education-System.

The Free Library (2014). Academic dishonesty and intention to cheat: a model on active versus passive academic dishonesty as perceived by business students. Retrieved from https://www.thefreelibrary.com.

\section{Appendix}

\section{MOLDOVAN QUESTIONS On ACADEMIC INTEGRITY}

1. name

2. age

3. student status

4. discipline or major

5. Romanian or Russian school or both

6. first language spoken/learned

7. How was the idea of group work introduced to you in your education?

8. How did your teachers encourage/direct students to complete tests, homework and projects?

9. How do you view dishonesty/unethical behavior in a business environment? In an academic environment?

10. Do you think it is wrong to be dishonest in your academic work? Why?

11. Do you think instances of academic dishonesty are more prevalent in Europe or the United States?

12. When are times it is acceptable to use the work of someone else as your own work for writing papers, completing exams or conducting research? Why?

13. Define plagiarism...Plagiarism is the "wrongful appropriation" and "purloining and publication" of another author's "language, thoughts, ideas, or expressions," and the representation of them as one's own original work

14. How are beliefs about academic dishonesty related or rooted to one's own cultural?

15. Why is engaging in academic dishonesty more socially acceptable in former Soviet Republics like Moldova?

16. Would you confront someone who you knew was not producing their own work for a class(es)? Why or Why not?

17. How do you think the instances of academic dishonesty changed since you were a younger student?

18. How do you think employers in Moldova view hiring graduates who have engaged in academic dishonesty?

19. Do you think this would be different in the United States?

20. Do you agree with this statement: Academic dishonesty is not a wide spread problem in the Moldovan educational system. Why or why not?

21. Which is more dangerous to your academic progress-passive dishonesty (letting some copy your original work) or active (using someone else's original work)?

22. How is being academically dishonest related to one's own ethical or moral beliefs?

23. Do you think academic dishonesty is more prevalent when students are younger or older? Why?

24. (e.g. Evans \& Craig, 1990; Ludeman, 1988; Schab, 1991).

25. Do you think males are more academically dishonest than females or vice versa? Why? 